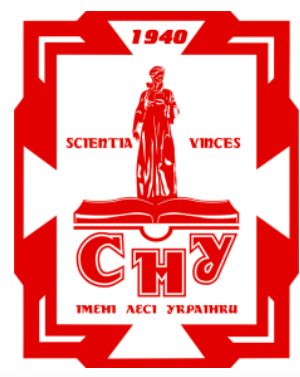

Науковий вісник Східноєвропейського національного університету

імені Лесі Українки

Розділ I. Ботаніка

Серія: Біологічні науки, 2019, 3 (387)

УДК 58.1:[661.162.65:582.707]

doi.org/10.29038/2617-4723-2019-387-5-10

\title{
Дія ретарданту фолікуру на морфогенез, накопичення вуглеводів та елементів живлення органами рослин агрусу у зв'язку з урожайністю культури
}

\section{Володимир Кур'ята, Галина Шаталюк}

Вінницький державний педагогічний університет імені Михайла Коцюбинського, Вінниця, Україна Адреса для листування: halya17061991@gmail.com

Отримано: 20.01.19; прийнято до друку: 20.02.19; опубліковано: 28.06.19

Резюме. Представлено результати досліджень впливу триазолпохідного ретарданту фолікуру на морфогенез, накопичення неструктурних вуглеводів, ключових елементів мінерального живлення та врожайність культури агрусу. Обробка рослин агрусу сорту Машенька 0,025 \%-м розчином фолікуру у фазі бутонізації позитивно впливала на формування мезоструктури листків: збільшувалася товщина хлоренхіми та листкової пластинки в цілому, зростали лінійні розміри й об'єм клітин стовпчастої та губчастої паренхіми, відбувалося накопичення хлорофілів. За дії препарату в листках та пагонах відкладалося більше неструктурних вуглеводів й елементів мінерального живлення, ніж у контролі. Такі зміни забезпечували необхідний резерв вуглеводів та елементів живлення для формування й росту плодів і приводили до суттєвого підвищення врожайності культури.

Ключові слова: агрус (Grossularia reclinat), ретарданти, морфогенез, фотосинтетичний апарат, продуктивність, елементи живлення.

\section{Effect of Retardants of the Folicur on Morphogenesis, Accumulation of Carbohydrates and Nutrition Elements of the Organs Plants in Gooseberry Leaves Related to the Crop Productivity}

\author{
Volodymyr Kuryata, Galina Shatalyuk \\ Vinnytsia Mikhail Kotsiubynskyi State Pedagogical University, Vinnitsa, Ukraine \\ Correspondence: halya17061991@gmail.com
}

Abstract. The paper presents the research results of the effect of the triazole derivative retrandant folicur on
morphogenesis, accumulation of nonstructural carbohydrates, key elements of mineral nutrition and yield of
gooseberry plants. Field small-land experiments were laid in $2015-2017$. Gooseberry plants of cv. Mashen'ka
were treated with a $0,025 \%$ solution of the folicur during the budding phase using a paddle sprayer. The
phytometric indices were determined every 10 days, the mesostructure was established in the middle-tier leaves
in the phase of the fruit formation, the content of the amount of chlorophylls was determined in the raw material
by the spectrophotometric method, the content of various forms of carbohydrates and elements of mineral
nutrition in plant organs was determined by biochemical methods in fixed dry material (content of sugars and
starch was estimated by the iodometric method, and the content of total nitrogen was determined with the help of
the Kjeldahl method). The treatment of the plants with the product positively influenced the formation of the leaf
'ята В., Шаталюк Г., 2019 
mesostructure - the thickness of the chlorenchyme and the leaf blade increased in general, the linear sizes and volume of the cells of the columnar and spongy parenchyma increased, chlorophylls accumulated. Under the action of the preparation more non-structural carbohydrates (sugars + starch) and mineral nutrients were accumulated in leaves and shoots in comparison with the plants of the control variant. Such changes provided the necessary reserve of carbohydrates and nutrients for the fruit formation and growth, causing a considerable increase in the crop productivity. Consequently, the triazole derivative retardant folicur, influencing the anatomical, morphological and physiological and also biochemical characteristics of the gooseberry plants, changed the nature of the donor-acceptor relationships in the plant, which intensified the production process and optimized the crop productivity.

Key words: gooseberry (Grossularia reclinat), retardants, morphogenesis, photosynthetic apparatus, productivity, elements supplies.

\section{Вступ}

Застосування синтетичних регуляторів росту й розвитку рослин $\epsilon$ перспективним напрямом рослинництва, оскільки дає змогу посилювати або вповільнювати ростові процеси на різних етапах розвитку, регулювати плодоношення та впливати на якість продукції. У рослинах функціонує донорно-акцепторна система, де в ролі донора (джерела) виступають фотосинтезуючі органи й тканини та процеси фотосинтезу, а в якості акцептора (стоку) - процеси росту, відкладання речовин у запас та зони активного метаболізму $[1,2]$. Із погляду фізіології, штучна зміна швидкості росту під впливом фітогормонів i синтетичних фізіологічноактивних речовин дає змогу змоделювати різний ступінь напруження між донорною та акцепторною сферами рослини, а отже, можливість корегувати формування й функціонування донорноакцепторних відносин на різних етапах онтогенезу $[3,4,5]$. Пізнання шляхів i механізмів функціонування та регуляції активності цієї системи, зокрема за допомогою штучного перерозподілу асимілятів до господарсько важливих органів (плодів, коренеплодів, інших органів запасу) під впливом фітогормонів i різних груп синтетичних регуляторів росту, відкриває нові можливості для оптимізації продуктивності сільськогосподарських культур [6]. Відомо, що функціонування донорної й акцепторної сфер у рослині взаємопов'язано різними системами регуляції таким чином, що швидкість росту визначає фотосинтетичну активність донорної сфери $[1,2,4]$. Оскільки регулятори росту рослин суттєво впливають на морфогенез, то з'являється можливість установити, через які анатомо-морфологічні й фізіологічні зміни посилюється або послаблюється транспорт потоків асимілятів до різних органів i тканин рослини. Такий підхід уможливлює встановлення не лише перерозподілу продуктів фотосинтезу між вегетативними та генеративними органами рослини, але й елементів мінерального живлення.
Однією 3 найбільш поширених груп регуляторів росту рослин $\epsilon$ ретарданти. Це синтетичні речовини, які застосовуються для регулювання ростової функції $[7,8]$, інтенсивності фотосинтетичних процесів як одиниці площі листка, так і цілої рослини й ценозу в цілому $[9,10,11]$. Ретарданти мають здатність впливати на процеси карпогегнезу, навантаження рослин плодами та насінням $[12,13]$, регулювати якість продукції [7, 8, 17], прискорювати перехід до стану спокою [18], підвищувати стійкість рослин до несприятливих факторів середовища [16]. Вони значно відрізняються за своєю хімічною будовою, однак викликають один і той самий ефект - уповільнюють поділ і розтягування клітин, що призводить до гальмування росту в цілому, не викликаючи аномальних відхилень. За механізмом дії це антигіберелінові препарати, які блокують синтез або дію вже синтезованого гормону [18]. Установлено, що обмеження швидкості ростових процесів препаратами цієї групи призводить до накопичення надлишку асимілятів, які використовуються для формування насіння та плодів. При достатній активності асиміляційного апарату штучне обмеження росту вегетативних органів під впливом ретардантів призводить до перерозподілу асимілятів у бік формування плоду, унаслідок чого часто підвищується врожайність i покращується якість сільськогосподарських культур [19]. Водночас у науковій літературі особливості впливу цієї групи регуляторів росту на морфогенез та формування й функціонування донорної та акцепторної сфер рослини у зв'язку 3 урожайністю сільськогосподарських культур вивчено недостатньо [11]. Серед сучасних ретардантів в останні роки достатньо ефективно використовуються триазолпохідні препарати, зокрема препарат фолікур, діючою речовиною якого $є$ тебуконазол. Препарат легко проникає в рослину через листя й корінь та покращує стійкість до вилягання завдяки потовщенню й 
укороченню стебла, а також покращує адаптивність рослин до несприятливих факторів середовища [20, 21]. Триазолпохідні ретарданти часто застосовують під час вирощування овочевих, технічних і кормових культур [6, 11, 21]. При цьому системного вивчення впливу триазолпохідних препаратів на морфогенез i продуктивність ягідних культур не проводили.

Мета роботи - установити особливості морфогенезу рослин агрусу, накопичення й перерозподілу асимілятів та азотовмісних сполук між органами за дії ретарданту фолікуру у зв'язку з продуктивністю культури.

\section{Матеріал і методи досліджень}

Польові дрібноділянкові дослідження проводили на насадженнях агрусу сорту «Машенька» фермерського господарства «Дагор» (с. Раково Томашпільського району Вінницької області) у вегетаційний період 2015-2017 р. Площа облікової ділянки - 10 м², повторність дослідів - п'ятиразова. Рослини обробляли за допомогою ранцевого оприскувача ОП-2 одноразово в період бутонізації 0,025 \%-м водним розчином фолікуру до повного змочування листків. Рослини контрольного варіанта обприскували водопровідною водою.

Довжину пагонів визначали кожні 10 діб. Мезоструктурну організацію листків вивчали наприкінці вегетації на фіксованому матеріалі. Для консервації листків застосовували суміш однакових частин етилового спирту, гліцерину й води 3 додаванням $1 \%$ формаліну. Визначення розмірів клітин і товщини хлоренхіми здійснювали за допомогою мікроскопа Микмед-1 та окулярного мікрометра МOB-1$15 \mathrm{x}$ у 20-кратній повторності. Мацеруючим агентом обрано 5 \%-й розчин оцтової кислоти в 2 М соляній кислоті. Для анатомічного аналізу відбирали листки середнього ярусу, які повністю закінчили ріст. Визначення вмісту хлорофілів проводили у свіжому матеріалі спектрофотометричним методом на спектрофометрі СФ-16. Уміст неструктурних вуглеводів (цукрів і крохмалю) визначали за допомогою йодометричного методу, уміст фосфору - за інтенсивністю утворення фосфорно - молібденового комплексу, калію полум'яно-фотометричним методом, уміст різних форм азоту - за Кельдалем. У зрілих плодах визначали показники якості: уміст цукрів, аскорбінової кислоти й загальну кислотність [22]. Результати досліджень обробляли статистично за допомогою комп'ютерної програми «Statistica 6». Застосовували однофакторний дисперсійний аналіз (відмінності між середніми значеннями обчислювали за критерієм Стьюдента, їх уважали вірогідними при $p \leq 0,05)$. У таблицях наведено середні дані за три роки досліджень.

\section{Результати та обговорення}

Отримані результати дослідження свідчать про типову рістгальмівну дію ретарданту фолікуру на ростові процеси. За дії препарату довжина однорічних пагонів агрусу сорту «Машенька» в кінці вегетації становила $22,16 \pm 1,80$ см проти 27,7 $\pm 1,13$ см контролю. Особливості структури фотосинтетичного апарату рослин суттєво впливають на фотосинтетичну продуктивність [4, 6]. Анатомічні структури листка, які мають відношення до фотосинтетичних процесів, у науковій літературі отримала назву «мезоструктура» [23]. Аналіз впливу ретарданту фолікуру на мезоструктурні показники свідчить про суттєвий вплив препарату на анатомічну будову листків агрусу (табл. 1). Установлено суттєве потовщення листків рослин дослідного варіанта, що $\epsilon$ показником більшої концентрації елементів, відповідальних за фотосинтез, на одиницю площі листка. Потовщення листка відбувалося як за рахунок збільшення товщини основної фотосинтетичної тканини хлоренхіми, так i внаслідок потовщення верхнього та нижнього епідермісів.

Установлено, що під впливом препарату збільшувалися розміри клітин асиміляційної паренхіми, про що свідчать показники об'єму клітин стовпчастої та довжини й ширини губчастої паренхіми. Аналогічні зміни мезоструктури листків за дії ретардантів відзначено й в інших культур [18].

Уміст хлорофілів - важлива характеристика фотосинтетичного апарату рослин. За дії фолікуру відбувалося достовірне зростання вмісту суми хлорофілів у листках рослин агрусу (див. табл. 1). Отже, в оброблених рослин під впливом ретарданту формувалася більш потужна донорна сфера рослини, що проявлялося в оптимізації мезоструктурної організації листка та накопичення фотосинтетичних пігментів. Такі зміни $\epsilon$ важливою передумовою підвищення врожайності культури.

Аналіз динаміки вмісту неструктурних вуглеводів (цукри + крохмаль) свідчить, що 
Дія ретарданту фолікуру на морфогенез, накопичення вуглеводів та елементів живлення органами рослин агрусу у зв'язку з урожайністю культури

\section{Вплив фолікуру на мезоструктурну організацію листків агрусу сорту «Машенька».}

\begin{tabular}{|c|c|c|}
\hline Показник & Контроль & Фолікур \\
\hline $\begin{array}{c}\text { Товщина } \\
\text { листка, }, \text { мкм }\end{array}$ & $244,0 \pm 8,03$ & $317,7 \pm 7,35^{*}$ \\
\hline $\begin{array}{c}\text { Товщина } \\
\text { хлоренхіми, } \\
\text { мкм }\end{array}$ & $208,2 \pm 5,36$ & $265,5 \pm 1,68^{*}$ \\
\hline $\begin{array}{c}\text { Товщина } \\
\text { верхнього } \\
\text { епідермісу, } \text { мкм }\end{array}$ & $18,1 \pm 0,62$ & $27,0 \pm 0,8^{*}$ \\
\hline $\begin{array}{c}\text { Товщина } \\
\text { нижнього } \\
\text { епідермісу, }, к м\end{array}$ & $17,7 \pm 0,42$ & $25,1 \pm 0,82^{*}$ \\
\hline $\begin{array}{c}\text { Об’єм клітин } \\
\text { стовпчастої } \\
\text { паренхіми, } \\
\text { мкм }\end{array}$ & $10305 \pm 555,2$ & $14795,1 \pm 371,4$ \\
\hline $\begin{array}{c}\text { Довжина клітин } \\
\text { губчастої } \\
\text { паренхіми, } м к м\end{array}$ & $28,1 \pm 1,55$ & $35,1 \pm 1,54^{*}$ \\
\hline $\begin{array}{c}\text { Ширина клітин } \\
\text { губчастої } \\
\text { паренхіми, } м к м\end{array}$ & $23,6 \pm 0,55$ & $26,1 \pm 0,55^{*}$ \\
\hline $\begin{array}{c}\text { Уміст } \\
\text { хлорофілу } \\
\text { (а+б), \% на } \\
\text { масу сирої } \\
\text { речовини }\end{array}$ & $0,56 \pm 0,021$ & $0,63 \pm 0,034^{*}$ \\
\hline
\end{tabular}

Примітка. * - різниия достовірна при $p \leq 0,05$.

зміни організації фотосинтетичного апарату за дії фолікуру призводять до більш інтенсивного накопичення асимілятів у тканинах вегетативних органів рослин агрусу. Як видно 3 результатів дослідження, у листках рослин агрусу за дії препарату протягом усього періоду онтогенезу відзначався більш високий уміст суми цукрів, редукуючих цукрів і сахарози, порівняно 3 контролем (табл. 2). Відомо, що внаслідок обмеження росту за дії ретардантів може створюватися надлишок асимілятів не лише в листках, але й в інших вегетативних органах. Депоновані таким чином резервні вуглеводи можуть бути використані під час формування плодів, насіння, вегетативних органів запасу. Аналіз отриманих даних свідчить, що в пагонах депонується значна частина цукрів, близька за вмістом до концентрації їх у листках. При цьому вони, очевидно, відіграють суттєву роль у процесах карпогенезу (формування та розвитку плодів) зменшення вмісту цукрів від фази цвітіння до фаз формування плодів і повної стиглості було більш суттєвим, ніж у листках, що, очевидно, пов'язано з більш інтенсивним відтоком до плодів. Аналогічні зміни відзначено й для вмісту крохмалю в листках та пагонах: за дії фолікуру вміст цього резервного полісахариду був більш високим, порівняно 3 контролем, протягом усього періоду розвитку.

Отже, гальмування лінійного росту пагона за одночасної перебудови мезоструктури листка за дії фолікуру сприяло посиленню синтезу неструктурних вуглеводів та їх накопиченню у вегетативних органах рослин агрусу, що підвищувало резерв вуглеводів для потреб формування й росту плодів.

У наших попередніх роботах установлено, що за дії ретардантів та інших регуляторів росту зміна активності ростових процесів супроводжується перерозподілом між донорною та акцепторною сферами рослини не лише пластичних речовин, але й елементів живлення - азоту, фосфору, калію [9]. Результати вивчення впливу фолікуру на вміст цих елементів у листках та пагонах агрусу протягом онтогенезу свідчать, що препарат викликає суттєві зміни в накопиченні елементів живлення (табл. 3). За дії фолікуру відбувалося збільшення вмісту азоту, фосфору та калію в тканинах листків і пагонів рослин агрусу, що створювало додатковий резерв для формування й росту плодів. На нашу думку, причина таких змін - зменшення біорозбавлення концентрації елементів унаслідок скорочення ростових процесів. Протягом онтогенезу відбувається поступове зменшення вмісту цих елементів у тканинах листків i пагона внаслідок їх використання на потреби формування й росту плодів.

Екзогенна регуляція донорно-акцепторної системи рослини за допомогою регуляторів росту дає змогу перерозподіляти потоки асимілятів між іiі органами, що, урешті, має на меті покращення врожайності культури. Отримані дані свідчать, що застосування фолікуру приводило до збільшення врожайності культури агрусу (табл. 4).

Важливими показниками ефективності застосування ретарданту $\epsilon$ якісні характеристики продукції: уміст аскорбінової кислоти, суми цукрів і загальної кислотності. Отримані результати свідчать, що застосування фолікуру приводить до підвищення показників умісту 
Вплив фолікуру на вміст цукрів і крохмалю у вегетативних органах рослин агрусу сорту «Машенька» (\% маси сухої речовини)

\begin{tabular}{|c|c|c|c|c|c|c|c|c|c|}
\hline \multirow[b]{2}{*}{$\begin{array}{c}\text { Фаза } \\
\text { розвитку }\end{array}$} & \multirow[b]{2}{*}{$\begin{array}{c}\text { Орган } \\
\text { рос- } \\
\text { Лини }\end{array}$} & \multicolumn{2}{|c|}{ Сума цукрів } & \multicolumn{2}{|c|}{ Редукуючі цукри } & \multicolumn{2}{|c|}{ Сахароза } & \multicolumn{2}{|c|}{ Крохмаль } \\
\hline & & 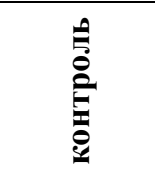 & 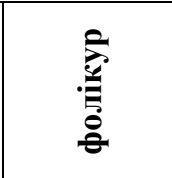 & 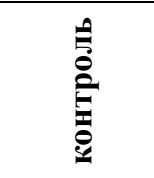 & לै. & : & 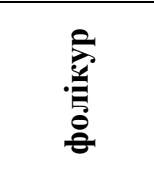 & 突 & $\sum_{\substack{0 \\
0}}^{0}$ \\
\hline \multirow{2}{*}{ Цвітіння } & Листок & $10,01 \pm 0,8$ & $10,7 \pm 0,84$ & $8,8 \pm 0,51$ & $9,6 \pm 0,62$ & $0,9 \pm 0,02$ & $1,3 \pm 0,06^{*}$ & $1,3 \pm 0,04$ & $1,2 \pm 0,03$ \\
\hline & Пагін & $10,8 \pm 0,12$ & $11,3 \pm 0,18^{*}$ & $10,5 \pm 0,16$ & $11,3 \pm 0,24 *$ & $0,8 \pm 0,01$ & $1,1 \pm 0,06^{*}$ & $1,3 \pm 0,01$ & $1,5 \pm 0,02 *$ \\
\hline \multirow{2}{*}{$\begin{array}{c}\text { Форму- } \\
\text { вання } \\
\text { плодів }\end{array}$} & Листок & $10,2 \pm 0,11$ & $11,2 \pm 0,26^{*}$ & $9,1 \pm 0,48$ & $10,4 \pm 0,18^{*}$ & $1,3 \pm 0,05$ & $1,5 \pm 0,01 *$ & $1,5 \pm 0,06$ & $1,7 \pm 0,01 *$ \\
\hline & Пагін & $6,7 \pm 0,12$ & $7,1 \pm 0,18$ & $6,1 \pm 0,36$ & $7,3 \pm 0,11^{*}$ & $0,7 \pm 0,07$ & $1,1 \pm 0,05^{*}$ & $1,7 \pm 0,02$ & $2,0 \pm 0,04^{*}$ \\
\hline \multirow{2}{*}{$\begin{array}{c}\text { Повна } \\
\text { стиглість } \\
\text { плодів }\end{array}$} & Листок & $10,3 \pm 0,11$ & $11,2 \pm 0,12 *$ & $9,2 \pm 0,12$ & $9,8 \pm 0,09 *$ & $1,1 \pm 0,01$ & $1,2 \pm 0,01 *$ & $1,1 \pm 0,01$ & $2,1 \pm 0,02 *$ \\
\hline & Пагін & $7,1 \pm 0,07$ & $8,6 \pm 0,02 *$ & $6,6 \pm 0,91$ & $7,6 \pm 0,17 *$ & $0,7 \pm 0,03$ & $0,8 \pm 0,02 *$ & $1,2 \pm 0,01$ & $2,4 \pm 0,01 *$ \\
\hline
\end{tabular}

Примітка. * - різниця достовірна при $p \leq 0,05$.

Таблиияя 3

Вплив фолікуру на вміст мінерального живлення у вегетативних органах рослин агрусу сорту «Машенька» (\% на масу сухої речовини)

\begin{tabular}{|c|c|c|c|c|c|c|c|}
\hline \multirow{2}{*}{$\begin{array}{c}\text { Фаза } \\
\text { розвитку }\end{array}$} & \multirow{2}{*}{ Орган } & \multicolumn{2}{|c|}{ Азослини } & \multicolumn{2}{|c|}{ Фосфор } & \multicolumn{2}{c|}{ Калий } \\
\cline { 3 - 8 } & контроль & фолікур & контроль & фолікур & контроль & фолікур \\
\hline \multirow{2}{*}{ Цвітіння } & Листок & $2,6 \pm 0,03$ & $2,7 \pm 0,05$ & $0,37 \pm 0,08$ & $0,39 \pm 0,07$ & $1,95 \pm 0,07$ & $2,07 \pm 0,02^{*}$ \\
\cline { 2 - 8 } & Пагін & $1,3 \pm 0,05$ & $1,8 \pm 0,04^{*}$ & $0,32 \pm 0,07$ & $0,37 \pm 0,05^{*}$ & $1,73 \pm 0,08$ & $1,81 \pm 0,09^{*}$ \\
\hline \multirow{2}{*}{$\begin{array}{c}\text { Формування } \\
\text { плодів }\end{array}$} & Листок & $2,4 \pm 0,02$ & $2,7 \pm 0,03^{*}$ & $0,33 \pm 0,08$ & $0,36 \pm 0,05^{*}$ & $1,86 \pm 0,06$ & $2,03 \pm 0,07^{*}$ \\
\cline { 2 - 8 } $\begin{array}{c}\text { Повна } \\
\text { стиглість } \\
\text { плодів }\end{array}$ & Листок & $2,4 \pm 0,02$ & $1,9 \pm 0,03^{*}$ & $0,21 \pm 0,04$ & $0,34 \pm 0,08^{*}$ & $1,64 \pm 012$ & $1,55 \pm 0,04^{*}$ \\
\cline { 2 - 8 } & Пагін & $0,9 \pm 0,03$ & $0,8 \pm 0,01$ & $0,23 \pm 0,02$ & $0,25 \pm 0,03^{*}$ & $1,02 \pm 0,2$ & $1,14 \pm 0,7^{*}$ \\
\hline
\end{tabular}

Примітка. * - різницяя достовірна при $p \leq 0,05$.

Вплив фолікуру на врожайність агрусу сорту «Машенька»

Таблиияя 4

\begin{tabular}{|c|c|c|c|c|c|}
\hline $\begin{array}{c}\text { Варіант/ } \\
\text { Показник }\end{array}$ & Урожай, $m / 2 a$ & $\begin{array}{c}\text { Урожайність із } \\
\text { куща, } к 2\end{array}$ & Кислотність, \% & $\begin{array}{c}\text { Аскорбінова } \\
\text { кислота, } \text { мг/100г }\end{array}$ & Сума цукрів, \% \\
\hline Контроль & $14,2 \pm 0,08$ & $2,9 \pm 0,92$ & $1,90 \pm 0,15$ & $20,8 \pm 0,70$ & $7,4 \pm 0,05$ \\
\hline Фолікур & $18,3 \pm 0,05^{*}$ & $3,7 \pm 0,07^{*}$ & $2,2 \pm 0,19$ & $24,2 \pm 0,51^{*}$ & $9,0 \pm 0,07^{*}$ \\
\hline
\end{tabular}

Примітка. * - різниця достовірна при $p \leq 0,05$.

аскорбінової кислоти та цукрів у ягодах, що є показником покращення якості продукції.

Незначне збільшення кислотності ягід перебуває в межах коливань, які $€$ типовими для агрусу за різних кліматичних умов вирощування.

\section{Висновки}

Застосування триазолпохідного ретарданту фолікуру в період бутонізації приводило до оптимізації функціонування донорноакцепторної системи рослин агрусу внаслідок кращого розвитку мезоструктури листків, накопичення хлорофілів, посилення синтезу нестроуктурних вуглеводів і накопичення їх й елементів мінерального живлення у вегетативних органах. Такі зміни забезпечували необхідний резерв вуглеводів та елементів живлення для формування й росту плодів та приводили до підвищення врожайності культури. 


\section{Література}

1. Bonelli, L. E.; Monzon, J. P.; Cerrudo, A.; Rizzalli, R. H.; Andrade, F. H. Maize grain yield components and source-sink relationship as affected by the delay in sowing date. Field Crops Research. 2016, 198, pp 215-225.

2. Yu, S. M.; Lo, Shuen-Fang, Ho.; Tuan-Hua David. Source-Sink Communication: Regulated by Hormone, Nutrient, and Stress Cross-Signaling. Trends in plant science. 2015, 20(12), pp 844-857.

3. Poprotska, I. V.; Kuryata, V. G. Features of gas exchange and use of reserve substances in pumpkin seedlings in conditions of skoto- and photomorphogenesis under the influence of gibberellin and chlormequat-chloride. Regulatory mechanisms in biosystems. 2017, 8(1).

4. Kiriziy, D. A.; Stasyk, O. O.; Pryadkina, G. A.; Shadchyna, T. M. Fotosintez. T. 2. Assimilyatsiya $\mathrm{CO}_{2} \mathrm{i}$ mehanizmy jejyo regulyatsii. Logos: Kiev, 2014 (in Russian).

5. Kuryata, V. G.; Poprotska, I. V.; Rogach, T. I. The impact of growth stimulators and retardants on the utilization of reserve lipids by sunflower seedlings. Regulatory mechanisms in biosystems. 2017, 8(3), pp 317-322.

6. Rogach, V. V.; Poprotska, I. V.; Kuryata, V. G. Effect of gibberellin and retardants on morphogenesis, photosynthetic apparatus and productivity of the potato. Visn. Dnipropetr. Univ. Ser. Biol. Ekol. 2016, 24(2), pp 416-419 (in Ukrainian).

7. Kasem, M. M.; Abd El-Baset, M. M. Studding the Influence of Some Growth Retardants as a Chemical Mower on Ryegrass (Lolium perenne L.). Journal of Plant Sciences. 2015, 3(5), pp 255-258.

8. Carvalho, M. E. A.; Castro, C. P. R.; Castro, F. M. V.; Mendes, A. C. C. Are plant growth retardants a strategy to decrease lodging and increase yield of sunflowerю. Comunicata Scientiae. 2016, 7(1), pp 154-164.

9. Kumar, S.; Sreenivas, G.; Satyanarayana, J.; Guha, A. Paclobutrazol treatment as a potential strategy for higher seed and oil yield in field-grown Camelina sativa L. Crantz. BSK Research Notes, 2012, 5(1), pp 13.

10. Zhang, W.; Xu, F.; Hua, C.; Cheng, S. Effect of chlorocholine chloride on chlorophyll, photosynthesis, soluble sugar and flavonoids of Ginkgo biloba. Not Bot Horti Agrobo, 2013, 41(1), pp 97-103.

11. Kuryata, V. G.; Kravets, O. O. Features of morphogenesis, accumulation and redistribution of assimilate and nitrogen containing compounds in tomatoes under retardants treatment. Ukrainian Journal of Ecology, 2018, 8(1), pp 356-362.

12. Koutroubas, S. D.; Damalas, C. A. Morphophysiological responses of sunflower to foliar applications of chlormequatchloride (CCC). Bioscience Journal, 2016, 32(6), pp 1493-1501.
13. Kuryata, V. G.; Polyvanyi, S. V. Formation and functioning of source-sink relation system of oil poppy plants under treptolem treatment in connection with productivity of crop. Ukrainian Journal of Ecology, 2018, 8(1), pp 11-20.

14. Li, N.; Li, J. M.; Zhai, Z.; Li, Z.H.; Duan, L.S. Effects of chemical regulator on the lodging resistance traits, agricultural characters and yield of maize. J Maize Sci, 2010, 18, pp 38-42.

15. Peng, D.; Chen, X.; Yin, Y.; Lu, K.; Yang, W.; Tang, Y.; Wang, Z. Lodging resistance of winter wheat (Triticum aestivum L.): Lignin accumulation and its related enzymes activities due to the application of paclobutrazol or gibberellin acid. F. Crop Res. 2014, (157), pp 1-7.

16. Fahad, S.; Hussain, S.; Saud, S.; Hassan, S.; Ihsan, Z.; Shah, A.N.; Wu, C.; Yousaf, M.; Nasim, W.; Alharby, H.; Alghabari, F.; Huang, J. Exogenously Applied Plant Growth Regulators Enhance the MorphoPhysiological Growth and Yield of Rice under High Temperature. Frontiers in Plant Science. 2016, 7, pp 1250.

17. Panyapruek, S.; Sinsiri, W.; Sinsiri, N.; Arimatsu, P.; Polthanee, A. Effect of paclobutrazol growth regulator on tuber production and starch quality of cassava (Manihot esculenta Crantz). Asian Journal of Plant Sciences. 2016, 15(1-2), pp 1-7.

18. Kuryata, V. G. (2009). Retardanty modyfikatory gormonalnogo status roslyn. Fiziologija roslyn: problem ta perspektyvy rozvytku. Logos: Kyiv, 2009, T.1

19. Altintas, S. Effects of chlormequat chloride and different rates of prohexadione-calcium on seedling growth, flowering, fruit development and yield of tomato. African Journal of Biotechnology. 2011, 10(75), pp 17160-17169.

20. Görtz, A.; Oerke, E. C.; Puhl, T.; Ulrike S. Effect of environmental conditions on plant growth regulator activity of fungicidal seed treatments of barley. Journal of Applied Botany and Food Quality. 2008, 82, pp 60-68.

21. Matysiak, K.; Kaczmarek, S. Effect of chlorocholine chloride and triazoles - tebuconazole and flusilazole on winter oilseed rape (Brassica napus var. oleifera L.) in response to the application term and sowing density. Journal of plant protection research. 2013, 53(1), pp 79-88.

22. AOAC. Official Methods of Analysis of Association of Analytical Chemist International $18^{\text {th }}$ ed. Rev. 3.2010. Asso. of Analytical Chemist. Gaithersburg, Maryland, USA, 2010.

23. Мокроносов А. Т. Методика количественной оценки структуры и функциональной активности фотосинтезирующих тканей и органов. Пр. труды по прикладной ботанике, генетике и селекции. 1978, 3, pp 119-131. 